\title{
СИСТЕМА РОЗПОДІЛУ ОБОВ'ЯЗКІВ ЩОДО ДЕРЖАВНОЇ ТА ГРОМАДСЬКОЇ ПІДТРИМКИ ВИДАВНИЧО-КНИГОТОРГОВЕЛЬНОЇ ГАЛУЗІ УКРАЇНИ
}

( А. О. Луценко, магістр, НТУУ «КПІ», Київ, Україна

Содействие - это, в первую очередь, внимание как государственных учреджений, так и общественных организаций. В статье систематизирована информация о функционирующих, на данный момент, организациях, оказывающих поддержку ИПК Украины, а также классифицирована информация о функциях, которые выполняют данные организации.

Assistance is, first of all, attention of Public as well as Private sector organizations. In this article relevant information about active organizations, which assist publishing and booktrading sectors of Ukrainian Economy is summarized. Information about functions, which these organizations implement, is classified.

\section{Постановка проблеми}

Кожна галузь економіки будь-якої країни є складним механізмом та вимагає підтримки 3 боку влади та громадськості. У випадку ігнорування з боку Держави її діяльність та розвиток помітно ускладнюється. Не є винятком і видавничо-книготорговельна галузь, адже книга є важливою інформаційною складовою сучасного суспільства.

Окрім того, книга - уречевлений результат праці та легко піддається впливу зовнішніх факторів, таких як: соціальні та економічні. Нині, в Україні активно змінюється економічна ситуація, відбувається перехід до глобальної економіки. Цей етап, безумовно, є складним і для видавничо-книготорговельного комплексу, адже, на сьогодні, як не прикро, йому приділяється все менше уваги.

\section{Аналіз попередніх} досліджень

Книга була і залишиться ключовим чинником у розвитку духовності та самоусвідомлення нації. Книговидання, як особливий елемент культурного життя суспільства, завжди було об'єктом уваги з боку органів державної влади, науковців та громадських діячів.

Так, роль книги у процесі державотворення з'ясовується в роботах О. Афоніна, С. Білоконя, В. Бурана, Л. Білкової, Н. Зелінської, Н. Зінченко, К. Індутної, Я. Ісаєвич, Т. Ківшар, Г. Ковальчук, М. Омелянчик, В. Семиноженка, М. Сенченка, М. Смирнова, Н. Солонської, Н. Стрішенець, Г. ШвецовоїВодки та ін.

Питання сучасного стану українського книговидання розглядають такі вчені: О. Афонін, 
І. Драч, А. Животок, Н. Зелінська, Е. Огар, В. Семиноженко, М. Сенченко, М. Тимошик.

\section{Мета роботи}

Метою даної роботи $€$ дослідження системи розподілу обов'язків щодо державної та громадської підтримки книговидання та книгорозповсюдження в Україні, систематизація та класифікація інформації, виявлення основних проблем з метою покращення ситуації.

\section{Результати проведених досліджень}

Українську систему підтримки видавничої та книготорговельної справи можна розділити на дві складові:

Державний сектор, у якому функціонують дві установи (табл. 1).

Недержавний сектор, у якому функціонують установи представлено в табл. 2.

Розподіл функціональних обов'язків відповідно до інфор-

Дані про заснування та функціональні підрозділи

Таблиця 1

\begin{tabular}{|c|c|c|}
\hline № & $\begin{array}{c}\text { Дата та умови утворення. } \\
\text { Особливості функціонування }\end{array}$ & $\begin{array}{c}\text { Функціональні підрозділи, } \\
\text { що мають відношення до ВПК }\end{array}$ \\
\hline 1. & \multicolumn{2}{|c|}{ Державний комітет телебачення та радіомовлення } \\
\hline & $\begin{array}{l}13 \text { травня } 1991 \\
\text { Утворено в результаті об'єднан- } \\
\text { ня Державного комітету УРСР } \\
\text { по пресі та Держкомтелерадіо } \\
\text { УРСР [7]. }\end{array}$ & $\begin{array}{l}\text { 1) } 20 \text { спеціалізованих державних видав- } \\
\text { ництв: у Києві - «Веселка», «Вища шко- } \\
\text { ла», «Дніпро», «Здоров'я», «Либідь», «Ми- } \\
\text { стецтво», «Музична Україна», «Техніка», } \\
\text { «Україна», «Українська енциклопедія ім. } \\
\text { М. П. Бажана», «Урожай», «Етнос»; у Дніп- } \\
\text { ропетровську - «Січ»; у Донецьку - } \\
\text { «Донбас»; у Львові- «Каменяр», «Світ»; } \\
\text { в Одесі - «Маяк»; в Ужгороді - «Карпа- } \\
\text { ти»; у Сімферополі- «Таврія», у Хар- } \\
\text { кові- «Основа» [7]. } \\
\text { 2) Державне підприємство «Видавництво } \\
\text { і друкарня «Таврида»; ДП «Полісервіс»; } \\
\text { Державна наукова установа «Книжкова } \\
\text { палата України імені Івана Федорова»; } \\
\text { Український інститут підвищення кваліфі- } \\
\text { кації працівників телебачення, радіомов- } \\
\text { лення і преси (Укртелерадіопресінститут); } \\
\text { ДП «Дирекція фестивально-виставкової } \\
\text { діяльності» [7]. }\end{array}$ \\
\hline 2. & \multicolumn{2}{|c|}{ Українське аґентство з авторських та суміжних прав } \\
\hline & $\begin{array}{l}7 \text { червня } 2000 \text { року } \\
\text { Утворено на базі Державного } \\
\text { агентства України з авторських і } \\
\text { суміжних прав. } \\
\text { Належить до сфери управління } \\
\text { Міністерства освіти і науки, мо- } \\
\text { лоді та спорту України та } \\
\text { підпорядковане Державному } \\
\text { департаменту інтелектуальної } \\
\text { власності Міністерства освіти і } \\
\text { науки, молоді та спорту України } \\
\text { [12]. }\end{array}$ & $\begin{array}{l}\text { Управління по роботі з користувачами } \\
\text { об'єктів авторського права. } \\
\text { Управління по роботі з правовласниками. } \\
\text { Управління міжнародних зв'язків. } \\
\text { Юридичне управління [12]. }\end{array}$ \\
\hline
\end{tabular}




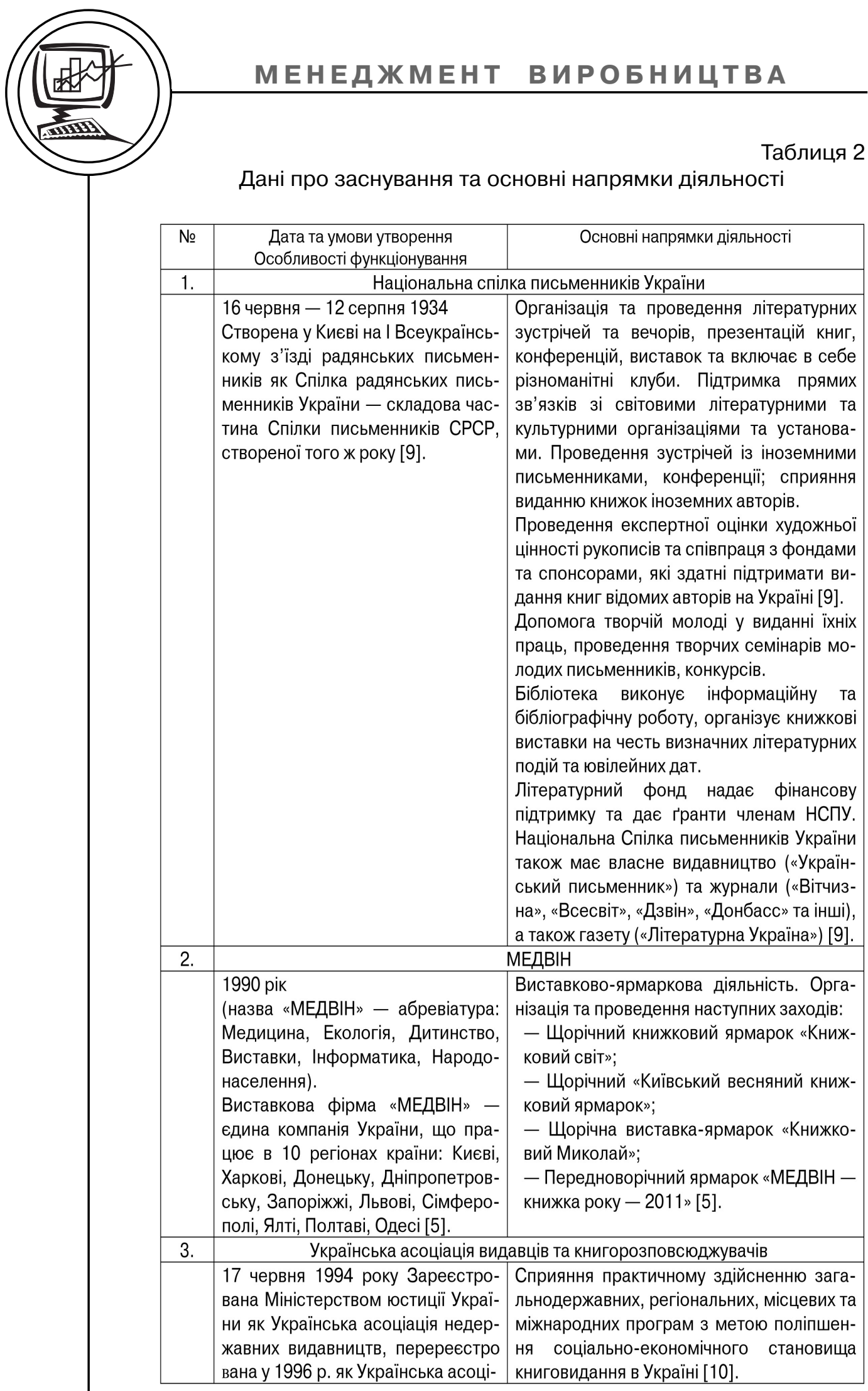


Продовження табл. 2.

\begin{tabular}{|c|c|c|}
\hline № & $\begin{array}{c}\text { Дата та умови утворення } \\
\text { Особливості функціонування }\end{array}$ & Основні напрямки діяльності \\
\hline & $\begin{array}{l}\text { ація видавців, а у } 2000 \text { р. іще раз } \\
\text { - як Українська асоціація видав- } \\
\text { ців та книгорозповсюджувачів } \\
{[10] .}\end{array}$ & $\begin{array}{l}\text { Сприяння реалізації науково-освітніх про- } \\
\text { грам вдосконалення видавничої справи та } \\
\text { сфери книгопоширення, програм націо- } \\
\text { нально-культурного розвитку. } \\
\text { Поліпшення матеріального становища } \\
\text { працівників видавничої та книготорго- } \\
\text { вельної сфер діяльності. } \\
\text { Надання допомоги у розвитку інформа- } \\
\text { ційного забезпечення та обміну Членів } \\
\text { Асоціації, а також талановитій творчій мо- } \\
\text { лоді [10]. }\end{array}$ \\
\hline 4. & \multicolumn{2}{|c|}{ Громадська організація «Форум видавців» } \\
\hline & $\begin{array}{l}1994 \text { рік } \\
\text { Неприбуткова громадська органі- } \\
\text { зація [5]. }\end{array}$ & $\begin{array}{l}\text { Основний напрямок діяльності - виставко- } \\
\text { ярмарковий. Серед заходів, що проводять- } \\
\text { ся є наступні: Міжнародний книжковий } \\
\text { «Форум видавців у Львові», Міжнародний } \\
\text { Літературний фестиваль, Конкурс дитячого } \\
\text { читання «Найкращий читач України», Фес- } \\
\text { тиваль дитячого читання «Книгоманія», } \\
\text { «Форум видавців - дітям», «Читацький ма- } \\
\text { рафон», Благодійна акція «Подаруй дитині } \\
\text { книжку!», виставка «Форум видавців у Вер- } \\
\text { ховній Раді», виставка «Форум видавців у } \\
\text { Секретаріаті Президента» [5]. }\end{array}$ \\
\hline 5. & \multicolumn{2}{|c|}{ Асоціація українських письменників } \\
\hline & $\begin{array}{l}\text { Жовтень } 1996 \text { року } \\
\text { Виникла під час роботи III-го з'їду } \\
\text { Спілки письменників України. } \\
319 \text { квітня } 2001 \text { року Асоціація } \\
\text { набула статусу Всеукраїнської } \\
\text { творчої спілки [2]. }\end{array}$ & $\begin{array}{l}\text { Організація видавничої діяльності, пошук } \\
\text { спонсорів. } \\
\text { У період з 2000-2001 було видано близь- } \\
\text { ко } 200 \text { видань [2]. }\end{array}$ \\
\hline 6. & \multicolumn{2}{|c|}{ Всеукраїнська асоціація видавців та розповсюджувачів преси } \\
\hline & $\begin{array}{l}1996 \text { рік } \\
\text { Одне } 3 \text { найстаріших громадських } \\
\text { об'єднань засобів масової інфор- } \\
\text { мації в Україні [4]. }\end{array}$ & $\begin{array}{l}\text { Вивчення ринку друкованої продукції, } \\
\text { створення умов та правил для розповсю- } \\
\text { джувачів друкованих ЗМІ в Україні. Інфо- } \\
\text { рмаційна, науково-методична, організа- } \\
\text { ційна та інша допомога видавцям та роз- } \\
\text { повсюджувачам періодичної друкованої } \\
\text { продукції. Співпраця з громадсько- } \\
\text { політичними організаціями з метою реалі- } \\
\text { зації та захисту політичних, економічних } \\
\text { та інших прав своїх членів, а також захист } \\
\text { прав громадян на вільний доступ до інфо- } \\
\text { рмації. Розвиток міжнародних зв'язків у } \\
\text { галузі видання та розповсюдження друко- } \\
\text { ваних засобів масової інформації [4]. }\end{array}$ \\
\hline
\end{tabular}




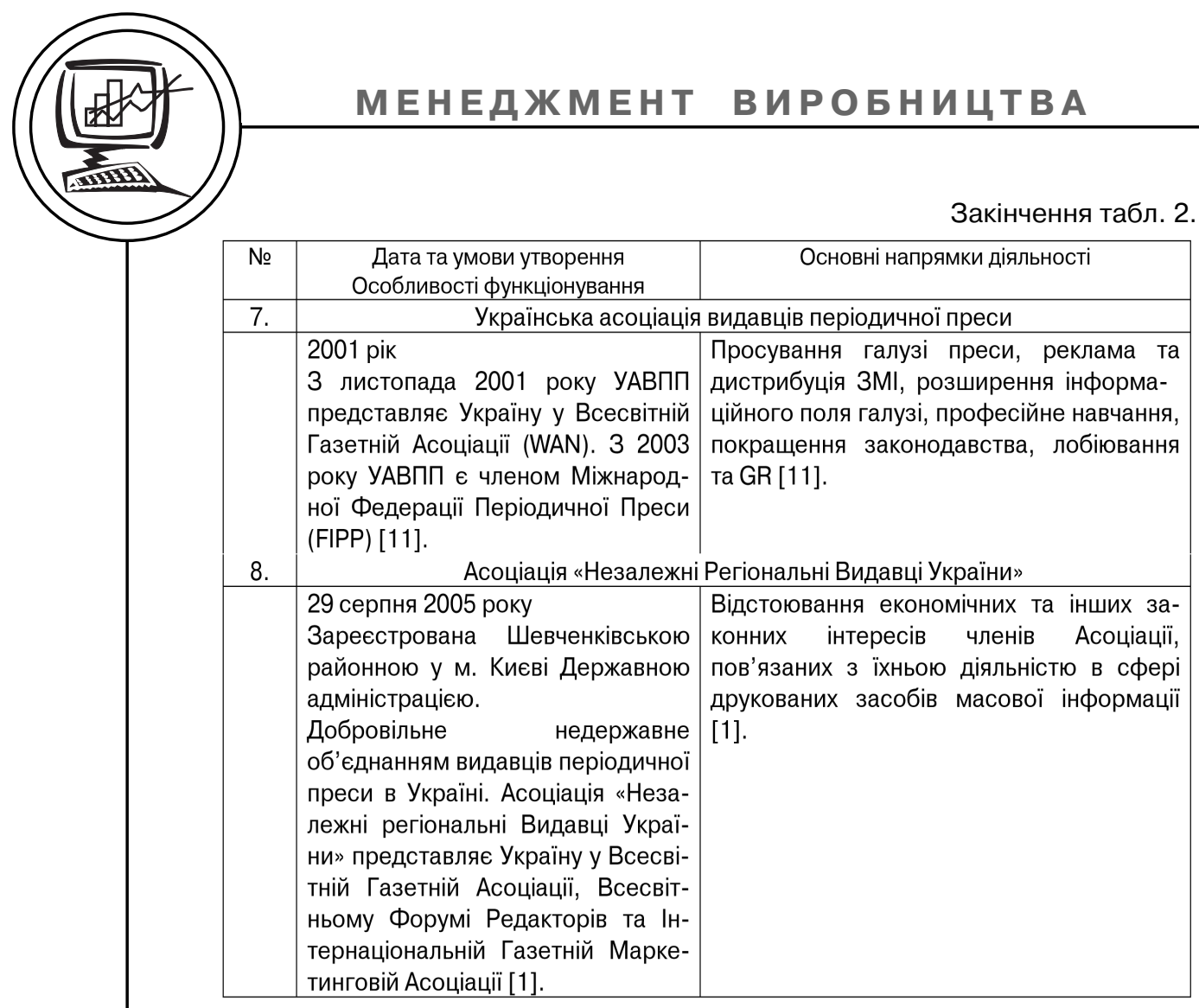

мації наданої на веб-сторінках установ:

Рекламно-інформативна функція

- Асоціація «Незалежні Регіональні Видавці України» (інформування галузі, партнерів галузі та фахівців) [1];

- Українська асоціація видавців періодичної преси (поширення інформації про ЗМІ в межах видавничо-книготорговельної та інших галузей) [11];

Освітня функція

- Асоціація «Незалежні Регіональні Видавці України» (професійна освіта, тренінги, семінари, тощо) [1];

- Державний комітет телебачення та радіомовлення (професійна освіта, курси підвищення кваліфікації) [7];

Дослідницька функція

- Українська Асоціація Видавців Періодичної Преси (вив-

чення ринку друкованої преси) [11];

- Всеукраїнська асоціація видавців та розповсюджувачів преси (вивчення ринку друкованої продукції) [4];

- Асоціація «Незалежні Регіональні Видавці України» (проведення досліджень галузі) [1];

Функція захисту прав та інтересів

- Державний комітет телебачення та радіомовлення (організація програм державної підтримки видання вітчизняної книги) [7];

- Українське агентство авторських та суміжних прав (управління майновими правами суб'єктів авторського, укладання договорів про збір та виплату авторської винагороди з користувачами творів, забезпечення збору авторської винагороди за 
публічне використання (сповіщення, показ, виконання, відтворення) творів на всій території України) [12];

- Асоціація «Незалежні Регіональні Видавці України» (сприяння роздержавленню ЗМІ, лобіювання інтересів у Верховній раді України) [1];

- Українська асоціація видавців періодичної преси (захист прав та інтересів розповсюджувачів та видавців преси) [11];

- Всеукраїнська асоціація видавців та розповсюджувачів преси (створення умов та правил для розповсюджувачів друкованих ЗМІ в Україні, співпраця з громадсько-політичними організаціями 3 метою реалізації та захисту політичних, економічних та інших прав своїх членів, а також захист прав громадян щодо вільного доступу до інформації) [4].

Комунікативна функція

- Національна спілка письменників України (підтримка зв'язків із світовими літературними та культурними організаціями) [9];

- Українська Асоціація видавців та книгорозповсюджувачів (забезпечення вільного обміну інформацією між учасниками Асоціації, організація форумів та круглих столів) [10];

- Всеукраїнська асоціація видавців та розповсюджувачів преси (розвиток міжнародних зв'язків у галузі видання та розповсюдження друкованих засобів масової інформації, вступ до міжнародних організацій видавців та розповсюджувачів друкованої продукції) [4];
- Українська Асоціація Видавців Періодичної Преси (формування цивілізованого ринку преси в Україні, системи розповсюдження періодики) [11].

Культурно-просвітницька функція

- Державний комітет телебачення та радіомовлення (організація виставково-ярмаркових заходів, конкурсів) [7];

- ГО «Форум видавців», МЕДВІН (Організація виставково-ярмаркових заходів, конкурсів, зустрічей 3 авторами, презентацій книг, тощо) $[3,5]$;

- Національна спілка письменників України (організація та проведення літературних вечорів, презентації книг, конференцій, виставки) [9];

- Громадська організація «Форум видавців» (організація просвітницьких заходів, мистецьких та культурних акцій, скерованих, перш за все, на сприяння творенню в Україні цивілізованого книжкового ринку) [5];

- Національна спілка письменників України (організація роботи із творчою молоддю) [9];

- Українська Асоціація видавців та книгорозповсюджувачів (організація роботи із творчою молоддю) [10];

- Асоціація «Незалежні Регіональні Видавці України» (проведення щомісячних фахових заходів) [1].

Статистична функція

- Державний комітет телебачення та радіомовлення (ведення державного реєстру суб'єктів видавничої справи) [7].

Функція об'єднання

- Українська Асоціація видавців та книгорозповсюджу- 


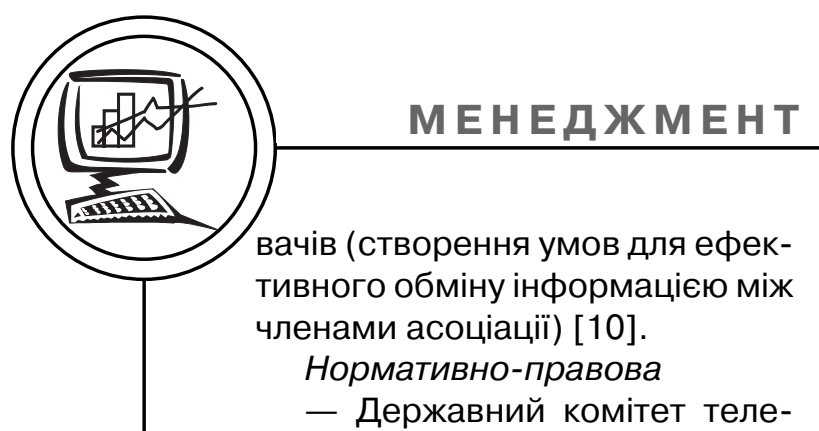
бачення та радіомовлення (розробка законопроектів щодо регулювання діяльності видавничо-книготорговельної галузі, видача документів дозвільного характеру суб'єктам ВПК (довідки про випуск та/або розповсюдження книжкової продукції державною мовою) [7];

- Асоціація «Незалежні Регіональні Видавці України» (надання юридичних консультацій) [1].

Функція допомоги

- Асоціація «Незалежні Регіональні Видавці України» (просування регіональної преси) [1];

- Всеукраїнська асоціація видавців та розповсюджувачів преси (інформаційна, організаційна та інша допомога видавцям та розповсюджувачам періодичної друкованої продукції) [4].

\section{Науково-методична функ- ція}

- Асоціація «Незалежні Регіональні Видавці України" (проведення досліджень, стандартизація) [1].

Окрім того, окремими установами ведеться робота щодо загального покращення становища книговидання та книгорозповсюдження в Україні, поліпшення матеріального становища видавців, сприяння реалізації програм національнокультурного розвитку, охорони та збереження культурної спадщини, створення умов, необхідних для творчості.

\section{Висновки}

Бачимо, що основною характеристикою української системи підтримки $є$ наявність в основному асоціації захисту прав авторів та окремих асортиментних груп видань (але не всіх). На державному рівні майже не приділена увага таким важливим складовим, як: мультимедійні видання, розвиток технологій типу pocketbook, електронним виданням. Відсутній чіткий поділ уваги відповідно до видів друку, за регіональним принципом, за цільовим та читацьким призначенням та ін.

Виявлено, що в українській системі відсутній чіткий розподіл обов'язків між гравцями на ринку, що призводить до дублювання обов'язків з одного боку та абсолютна відсутність виконавців з іншого, а це, в свою чергу, значно ускладнює умови ведення бізнесу та регулювання галузі. Відповідальність за розробку нових законопроектів щодо підтримки видавничої та книготорговельної галузей бере на себе лише Держкомтелерадіо.

Зауважимо, також, що такі функції, як: об'єднання, науково-методична, допомоги, що мали б вестися на базі державної організації Держкомтелерадіо, повністю покладені на недержавні установи.

Серед чинників проблем на українському просторі слід виділяти відсутність наступних складових:

- чіткого розподілу обов'язків між гравцями на ринку;

- єдиної системи контролю за виконанням функціональних обов'язків; 
- єдиної для всіх гравців ринку, система звітності;

- єдиної бази даних типу «Books in Print»;

- комплексного аналізу стану книжкового ринку (структури попиту та пропозиції, вікового аналізу, відповідно до рівня добробуту населення, мовного аспекту, регіонального, а не тільки кількості торговельних точок по всій Україні) на державному рівні (в Україні такий аналіз здійснює лише недержавна організація GfK Ukraine, прикладом може бути дослідження проведене у 2003 Інститут соціально-політичних досліджень РАН);

- відповідності законодавчої бази до реальних проблем книговидавничого та книготорговельного секторів;

- Ради галузевих фахівців зі створення законопроектів;
- дифференційного підходу до вирішення проблем та підтримки окремих складових видавничо-книготорговельного сектору економіки;

- єдиної системи відслідковування руху інформації, яка дасть можливість контролювати процес використання інформації із дотриманням норм авторських прав та захищати авторів від протизаконного використання їх творів.

Всі ці складності та недоліки, на превеликий жаль, ведуть до зниження конкурентоспроможності та прибутковості такого сектора Української економіки як видавничо-книготорговельний. Але політика підтримки має починатись 3 ініціативи Держави. Тільки в цьому випадку система буде працювати злагоджено та приносити очікуваний результат.

1. Асоціація «Незалежні регіональні видавці України» [Електронний ресурс] : [сайт] : україн. версія. - Текст. та граф. дані. - К., 2011. - Режим доступу : http://airpu.org/?area_id=37\&lang=1 (дата звернення 20.01.2012). - Назва з екрана. 2. Асоціація українських письменників [Електронний ресурс] : [сайт] : україн. версія. - Текст. та граф. дані. - К., 2011. - Режим доступу: http://uk.wikipedia.org/ (дата звернення 20.01.2012). - Назва з екрана. 3. Виставки Медвін [Електронний ресурс] : [сайт] : україн. версія. - Текст. та граф. дані. - К., 2011. - Режим доступу : http://medvin.kiev.ua/ (дата звернення 20.01.2012). - Назва $з$ екрана. 4. Всеукраїнська асоціація видавців та розповсюджувачів преси [Електронний ресурс] : [сайт] : україн. версія. - Текст. та граф. дані. - К., 2011. Режим доступу : http://www.uappd.com.ua/ (дата звернення 20.01.2012). Назва з екрана. 5. Громадська організація «Форум видавців» [Електронний ресурс] : [сайт] : україн. версія. - Текст. та граф. дані. - К., 2011. - Режим доступу : http://bookforum.ua/ (дата звернення 20.01.2012). - Назва з екрана. 6. Державний комітет телебачення та радіомовлення [Електронний ресурс] : [сайт] : україн. версія. - Текст. та граф. дані. - К., 2011. - Режим доступу : http://comin.kmu.gov.ua/ (дата звернення 20.01.2012). - Назва 3 екрана. 7. Індутка К. Книжковий ринок в Україні : стан розвитку та напрями державного регулювання / К. Індутка // Вісник КНТЕУ, 2009. - № 4. С. 46-524. 8. Національна спілка письменників України [Електронний ресурс] : [сайт] : україн. версія. - Текст. та граф. дані. - К., 2011. - Режим доступу : http://nspu.org.ua/ (дата звернення 20.01.2012). - Назва з екрана. 9. Українська асоціація видавців та книгорозповсюджувачів [Електрон- 
ний ресурс] : [сайт] : україн. версія. - Текст. та граф. дані. - К., 2011. Режим доступу : http://uabooks.info/ (дата звернення 20.01.2012). - Назва з екрана. 10. Українська асоціація видавців періодичної преси [Електронний ресурс] : [сайт] : україн. версія. - Текст. та граф. дані. - К., 2011. Режим доступу : http://www.uapp.org/ (дата звернення 20.01.2012). - Назва з екрана. 11. Українське агентство авторських та суміжних прав [Електронний ресурс] : [сайт] : україн. версія. - Текст. та граф. дані. - К., 2011. - Режим доступу : http://www.uacrr.kiev.ua/ua.about (дата звернення 20.01.2012). - Назва з екрана.

1. Asotsiatsiia «Nezalezhni rehionalni vydavtsi Ukrainy» [Elektronnyi resurs] : [sait] : ukrain. versiia. - Tekst. ta hraf. dani. - K., 2011. - Rezhym dostupu : http://airpu.org/?area_id=37\&lang=1 (data zvernennia 20.01.2012). - Nazva z ekrana. 2. Asotsiatsiia ukrainskykh pysmennykiv [Elektronnyi resurs] : [sait] : ukrain. versiia. - Tekst. ta hraf. dani. - K., 2011. - Rezhym dostupu: http://uk.wikipedia.org/ (data zvernennia 20.01.2012). - Nazva z ekrana. 3. Vystavky Medvin [Elektronnyi resurs] : [sait] : ukrain. versiia. - Tekst. ta hraf. dani. - K., 2011. - Rezhym dostupu : http://medvin.kiev.ua/ (data zvernennia 20.01.2012). - Nazva z ekrana. 4. Vseukrainska asotsiatsiia vydavtsiv ta rozpovsiudzhuvachiv presy [Elektronnyi resurs] : [sait] : ukrain. versiia. - Tekst. ta hraf. dani. - K., 2011. - Rezhym dostupu : http://www.uappd.com.ua/ (data zvernennia 20.01.2012). - Nazva z ekrana. 5. Hromadska orhanizatsiia «Forum vydavtsiv» [Elektronnyi resurs] : [sait] : ukrain. versiia. - Tekst. ta hraf. dani. K., 2011. - Rezhym dostupu : http://bookforum.ua/ (data zvernennia 20.01.2012). - Nazva z ekrana. 6. Derzhavnyi komitet telebachennia ta radiomovlennia [Elektronnyi resurs] : [sait] : ukrain. versiia. - Tekst. ta hraf. dani. - K., 2011. - Rezhym dostupu : http://comin.kmu.gov.ua/ (data zvernennia 20.01.2012). - Nazva z ekrana. 7. Indutka K. Knyzhkovyi rynok v Ukraini : stan rozvytku ta napriamy derzhavnoho rehuliuvannia / K. Indutka // Visnyk KNTEU, 2009. - № 4. - S. 46-524. 8. Natsionalna spilka pysmennykiv Ukrainy [Elektronnyi resurs] : [sait] : ukrain. versiia. - Tekst. ta hraf. dani. - K., 2011. - Rezhym dostupu : http://nspu.org.ua/ (data zvernennia 20.01.2012). - Nazva z ekrana. 9. Ukrainska asotsiatsiia vydavtsiv ta knyhorozpovsiudzhuvachiv [Elektronnyi resurs] : [sait] : ukrain. versiia. - Tekst. ta hraf. dani. - K., 2011. - Rezhym dostupu : http://uabooks.info/ (data zvernennia 20.01.2012). - Nazva z ekrana. 10. Ukrainska asotsiatsiia vydavtsiv periodychnoi presy [Elektronnyi resurs] : [sait] : ukrain. versiia. - Tekst. ta hraf. dani. - K., 2011. - Rezhym dostupu : http://www.uapp.org/ (data zvernennia 20.01.2012). - Nazva z ekrana. 11. Ukrainske ahentstvo avtorskykh ta sumizhnykh prav [Elektronnyi resurs] : [sait] : ukrain. versiia. - Tekst. ta hraf. dani. K., 2011. - Rezhym dostupu : http://www.uacrr.kiev.ua/ua.about (data zvernennia 20.01.2012). - Nazva z ekrana. 